\title{
Lumen
}

Selected Proceedings from the Canadian Society for Eighteenth-Century Studies

\section{Elisabetta Mosconi's Letters to Giovanni Antonio Scopoli: A Noble Marriage Negotiation at the Turn of the Nineteenth Century in Verona}

\section{Susan Dalton}

Volume 18, 1999

Representations of Time in the XVIIIth Century

Le temps et ses représentations au dix-huitième siècle

URI : https://id.erudit.org/iderudit/1012366ar

DOI : https://doi.org/10.7202/1012366ar

Aller au sommaire du numéro

Éditeur(s)

Canadian Society for Eighteenth-Century Studies / Société canadienne d'étude du dix-huitième siècle

ISSN

1209-3696 (imprimé)

1927-8284 (numérique)

Découvrir la revue

Citer cet article

Dalton, S. (1999). Elisabetta Mosconi's Letters to Giovanni Antonio Scopoli: A Noble Marriage Negotiation at the Turn of the Nineteenth Century in Verona. Lumen, 18, 45-67. https://doi.org/10.7202/1012366ar

Copyright (c) Canadian Society for Eighteenth-Century Studies / Sociéte canadienne d'étude du dix-huitième siècle, 1999
Ce document est protégé par la loi sur le droit d'auteur. L'utilisation des services d'Érudit (y compris la reproduction) est assujettie à sa politique d'utilisation que vous pouvez consulter en ligne.

https://apropos.erudit.org/fr/usagers/politique-dutilisation/ 


\section{Elisabetta Mosconi's Letters to Giovanni Antonio Scopoli: A Noble Marriage Negotiation at the Turn of the Nineteenth Century in Verona ${ }^{1}$}

It is difficult to know where to start talking about late eighteenth- and early nineteenth-century Italian noble women because of the lack of research concerning them. Moreover, the little that has been written tends to concentrate more on the ideals held out to women rather than investigating how women actually appropriated gender prescriptions. ${ }^{2}$ Some attempts have been made in the last ten years to present a more accurate picture of women's real-life experiences in both the fields of Italian literature and history, but these works, in their effort to build frameworks in which to situate further research, necessarily remain very general. ${ }^{3}$ Furthermore, they continue to rely on the public/private distinction which defines women as modest, soft, humble, sentimental and engaged with matters proper to household and family, despite the fact that they are strongly influenced by French scholarship, which has begun to call this rigid categorization into question. ${ }^{4}$ Thus, the time is ripe, it seems, to begin to undertake detailed case studies out of which more subtle interpretations - interpretations which can accommodate a multitude of different experiences - can be drawn. ${ }^{5}$ In this spirit, I would like to examine the marriage negotiations that Elisabetta Mosconi Contarini undertook with her future son-in-law, Giovanni Antonio Scopoli, on behalf of her daughter, Laura.

Before I turn directly to the letters that will serve as my source, however, I would like to set the stage by briefly presenting the correspondents and describing their relation as it concerns the norms of marriage negotiation in eighteenth-century Europe. Sadly, very little of this contextual information is available. We know that Elisabetta Mosconi Contarini, a countess, ${ }^{6}$ was born in either 1751 or $1752^{7}$ and that she died in 1807. She lived in Verona, and spent many summers at Novare, the Mosconi family's summer villa just outside the city. She was married to Giacomo Mosconi and had four children, all girls: Marietta, Clarina, Laura and Clementina. As for her interests and activities, we 
know from her letters that she was educated and cultured. She spent her days writing letters, receiving guests in her salon, going to the theatre, reading, and visiting with friends, including some of the most renowned literary figures of the time: Ippolito Pindemonte, Giovanni Cristofano Amaduzzi, Clementino Vannetti, Melchiorre Delfico, and Silvia Curtoni Verza. More is known about Giovanni Antonio Scopoli. He was born in 1774 in Shemnitz, Hungary (now Banska Stiavnika, Slovakia), his father was a doctor and naturalist, and the family moved to Padua in 1776 when the father received a university teaching post in chemistry and botany. Scopoli's father died in 1788, and Scopoli received his laurea in medicine from the University of Padua in 1793. He worked as a doctor in Rimini in 1798, and as a government administrator in the department of Olona in 1800. From this point on, he had a number of administrative posts in the Napoleonic government until 1814, when the Austrians took control of Milan, where Scopoli was stationed at the time. He continued on in his duties for a short time until he was dismissed by the Austrian government, at which point he returned to Verona. There, he lived a private life until his imprisonment in 1848 . He was then deported to Salzburg for the duration of the Lombardo-Veneto war. ${ }^{8}$ He died in 1854. As well as being an important government official, Scopoli was a man of culture. In Verona, he was a member of the Accademia d'agricoltura, commerci ed arti and of the Istituto veneto di scienze, lettere ed arti and the author of several texts on public education. ${ }^{9}$ As far as his social status is concerned, he was a knight of the Ordine della Corona di Ferro, ${ }^{10}$ and was conferred the title of count when he became part of the nobility on November 16, 1817. ${ }^{11}$ Thus, Scopoli would become a man of significant accomplishments. At the time that Mosconi met him, however, he was simply a 27 year-old with promise from a family with a certain amount of status and thus lower down on the social scale than Mosconi.

Within this context, Scopoli's marriage to Mosconi's daughter which took place on December 16, 1802,12 15 years before Scopoli was ennobled - seems to have been a misalliance. From the literature on European marital strategies in this period, the usual explanation for Mosconi's concession regarding social station would have been Scopoli's wealth. ${ }^{13}$ This does not seem to have been the case. Giuseppe Franco Viviana states that Scopoli's father's death left the family in the most squalid poverty. ${ }^{14}$ Furthermore, Mosconi not only seems to make a few remarks about the unfortunate state of his domestic economy (letter 4, July 5, 1801; letter 27, December 26, 1801), ${ }^{15}$ but also mentions salary as a matter Scopoli should take into account in considering employment opportunities; she even states that she does not necessarily wish him to be rich, but wants to see him in an honourable post, implying that he was not already in possession of a great deal of money (letter 11, 16 Fruttifero 
[September 3], 1801). Several other factors may have motivated the match. On the one hand, it may have been a sign of desperation on Mosconi's part. It may have signalled a degeneration of her family's situation; Mosconi's position as a widow might have forced her to be more flexible in her demands for her daughters; Mosconi may have feared that her daughter's illegitimate status might affect her attractiveness. $^{16}$

On the other hand, the decision to bring Scopoli into the family may have represented an opportunity of regeneration if Scopoli could increase the family patrimony, and was not necessarily a great compromise. ${ }^{17}$ Whatever the cause and whatever the degree, the effect of the inequality in the bargaining process is evident: Mosconi makes all the demands - demands which Scopoli eagerly tries to meet. Both seem to agree that Scopoli must find employment that would elevate him to a position worthy of her daughter. Further proof of the inequality can be found in Mosconi's insistence on keeping the engagement quiet until Scopoli succeeded in acquiring a suitable post (letter 12, 21 Fruttidoro [September 8], 1801; letter 14, 3 Vendemiaso [September 20], 1801). Finally, mention of the dowry, when it does come, is almost an afterthought, and, while it is possible and probably likely that discussions over this issue took place in person, the little attention it receives in Mosconi's letters suggests that it was not a subject over which there was serious haggling.

Within this very general context, I would like to focus on two issues. First, I have identified three separate voices assumed by Mosconi during the negotiation: that of surrogate parent (where Mosconi consoles and counsels Scopoli), that of in-law (where she is defending her daughter's best interests in the negotiation process) and that of romantic proxy (where she is giddy and adulatory towards Scopoli). Not only are these three voices present in the correspondence, they also fuse into various combinations. Mosconi sometimes integrates the role of romantic proxy with that of parent, for example. Rather than representing this combination as idiosyncratic, I think that it is possible to assert that the parental and romantic roles were more easily overlapped in the eighteenth century, an affirmation which gains credibility when we compare Mosconi's correspondence with that of Elisabeth Bégon, the wife of the governor of Trois Rivières, who also wrote in what seems to be a romantic tone to her son-in-law.

I would also like to argue that the correspondence provides us with an opportunity to view power in a new way. Mosconi clearly had the upper hand in her dealings with Scopoli, even though the avenues that she used to exert her influence were informal. Traditional divisions of public and private would place Mosconi's actions in the private sphere, 
as she was working on behalf of her family and held no official position. To understand her authority in this way, however, would be to do violence to the logic of her exchange with Scopoli and to seriously misrepresent her social position. In order to achieve the goal she desired - in this case, finding Scopoli suitable employment - she already had to possess a certain authority that was publicly recognized. To concede this is also to concede that the division between public and private, and its ancillary division, that of power and influence, has to be rethought. I will return to these two questions at the end of my article, but for now, I would like to undertake a closer analysis of Mosconi's correspondence with Scopoli.

Mosconi began to write to Scopoli shortly after they were introduced (letter 1, 10 Pratile [May 30], 1801), and continued to write to him regularly for over a year. Her correspondence ended, with the exception of one final letter, ${ }^{18}$ when he received a post in Verona, just a few months before the marriage to her daughter, Laura (letter 51, August 18, 1802). The body of letters, which, on average, were one to two pages in length, can be divided into three phases. The first, spanning from May 10, 1801 to August 5, 1801, I will call the honeymoon phase, in which Mosconi is delighted to have found Scopoli for her daughter: the tone is flattering and enthusiastic. The second section, the longest, beginning August 28, 1801, and ending May 23, 1802, is the negotiation phase, in which the terms for the marriage are expressed and resolved. The third phase, which consists of only 3 letters, is the resolution phase, in which all conditions have been satisfactorily met and pre-wedding pleasantries are exchanged.

\section{The Honeymoon Phase}

In the first phase of the correspondence, we hear all three of Mosconi's voices: that of surrogate parent, that of in-law and that of romantic proxy. The main way in which Mosconi assumed her role as in-law, that which is most consistently present throughout the correspondence, was through her concern over assuring Scopoli's elevated status through his career. In fact, we hear this voice not only in the first section, but in the very first letter. On May 30, 1801, she is already making use of her connections in an attempt to find him employment (letter 1, 10 Pratile [May 30], 1801). She mentions that she had already been able to help him in some way while he was in Verona (for which he has thanked her in a previous letter) and evaluates the potential utility of two of her friends in the provincial government of Verona. These are but the first of numerous attempts on her part to use her influence on his behalf. 
Her concern over his lack of employment is expressed in a number of ways. Even in the midst of her compliments, she often laments his bad fortune. First, she regrets his family's situation: '[a]nd why are your family's circumstances so difficult and unpleasant?'19 $T$ Then, in letter 6 (July 16,1801), she writes of the 'extraneous circumstances which oppose our mutual happiness. ${ }^{20}$ Finally, in letter 8 (August 2, 1801), she explicitly states how bad his luck has been:

I must ask you, my Scopoli, if you would consider a position in law? There is someone, who, by his heart, would strive to give it to you. Oh God! and what do you want? I do not know what I would give to see you in an honourable post, which would place you in this blessed mediocrity which would be enough to fulfil our common wish. Would that time either lessen this bitter and lovely passion, or favourably change your unjust fortune. ${ }^{21}$

The attention Mosconi focuses on Scopoli's career and on his family's social and economic position show that she was thinking of her daughter's future welfare, placing her in the somewhat adversarial position of in-law with regard to Scopoli.

Nevertheless, this concern over Scopoli's position coexists with equal amounts of joy. Indeed, the abundance of her expressions of appreciation and flattery set the tone for the first nine letters: even though she does show her concern for his employment prospects, Mosconi wants to communicate that she is happy with the tentative deal they have struck. For example, in her third letter of June 25, 1801, she exclaims how lucky Scopoli's mother is to have him as a son:

Oh my Scopoli, you have made me feel my inferiority through your proposal to come to live with me at Novare. I do not know what of your nature you owe to your mother, of whom you are such a virtuous son? Oh, what a truly fortunate mother! $!^{22}$

In letter 4, written July 5, 1801, she expresses her own good fortune at having found him, writing, '[o]h where would I find a son of better character, closer to my heart's wishes. ${ }^{23}$ And again in letter 6, she wonders where she was able to find a man for Laura who so united 'so many and such beautiful moral qualities, a more sensitive and pure soul, a heart made so truly one for the other. ${ }^{24}$

All of these sentiments are proper to an in-law, but they are not the only expressions of affection on Mosconi's part. She also seems to harbour feelings which are more intense, and, from a modern perspective, seem a little surprising. For example, when Mosconi's bubbling enthusiasm reaches its high point in letter 7 , she writes, 
Io $\mathrm{m}$ 'interesso tanto io penso tanto a voi, che certo il ben vostro non può essermi più a cuore di quello che me lo è quello delle proprie mie figlie, e non siete voi il caro l'ottimo figlio del mio affetto? Oh Scopolino mio quanto ti amo ti stimo e quanto la mia anima accarezza la tua immagine, la qual rapresentami le rare doti del tuo spirito, e le delicate ed eroiche virtù del tuo cuore! Voi sapete che vi ho scritto altra volta raccomandandomi ai caldi uffici vostri in favore della congregazione de' Preti Filippini di Verona... (letter 7, July 23, 1801)

I have such a great interest in you, and think of you so often, that surely your well-being can be no closer to my heart than that of my own daughters. Are you not the dear, excellent son of my affection? Oh my Scopolino, how I love you, esteem you, and how my soul caresses your image, which to me represents the rare gifts of your spirit and the delicate and heroic virtues of your heart! You know that I have again written calling on your warm offices in the favour of the Congregation of the Preti Filippini of Verona...

In addition to the fervent tone of the passage, the alternation between the ' $t u$ ' form, the familiar form of address, and the ' $v o i$ ', or formal, form is also significant. It is the first of only six occasions that Mosconi uses the ' $t u$ ' form in addressing Scopoli, which is normally reserved for her letters to her immediate family and Aurelio Bertola during the period they were romantically involved. On first reading, the second sentence (in which the ' $t u$ ' form is employed) represents a smooth and steady escalation from sentence which precedes it. Mosconi so laments his lack of employment opportunities - which she has been discussing in the few sentences preceding the passage - that she works herself to almost fever pitch, abandoning herself to a few giddy moments of impropriety.

Perhaps this is the case. But upon reflection, it becomes clear it is also possible to interpret the passage in order to draw very different information from it. In order to do so, we must first cast doubt on the proposition that Mosconi's use of ' $t u$ ' is a momentary lapse or an unconscious slip. In studying French correspondence from the same period, Benoît Melançon makes clear that no matter how much authors affirm that their letters are spontaneous, they are, in fact, very carefully crafted. ${ }^{25}$ Thus forewarned, if we return to our passage, we can see that the slip into the ' $t u$ ' form was perhaps in fact more of a step: the ' $t u$ ' sentence is sandwiched between two sentences which employ the ' $v o i^{\prime}$ form. What is the difference between the middle sentence and the two that surround it?

At one level, the very shift from ' $v o i$ ' to ' $t u$ ' indicates that Mosconi is switching roles in the middle sentence. The 'voi' form is the one she usually uses in addressing Scopoli as a prospective in-law. Even after he is married to Laura, in her last letter to Scopoli on April 19, 1804, Mosconi 
addresses him in this way. By contrast, the ' $t u$ ' form that she employs in the next sentence is used almost exclusively with immediate family and her lover. Which role is she playing here? Both. First, Mosconi wants Scopoli to understand that she feels as much affection for him as she does for her other children. This interpretation is further reinforced by the fact that Mosconi often says that Scopoli is her 'chosen son. ${ }^{26}$ Moreover, on the other rare occasions that she employs the ' $t u$ ' form with Scopoli in the negotiation phase, she is doing so as a way of cementing family relations. The tone is conspiratorial and maternal as she consoles him (letter 11, 16 Fruttifero [September 3], 1801; letter 39, April 3, 1802; letter 41, April 18, 1802) and teases him about a rival for Laura's affection (letter 19 , November 1, 1801). Furthermore, the ' $t u$ ' form often creeps in at the end of the letter, the space reserved for family news and greetings.

To interpret the use of the ' $t u$ ' form as being solely indicative of Mosconi's desire to claim Scopoli as her own son, however, would be mistaken: not only in this letter, but also in other passages of her first ten letters, Mosconi is excited and giddy in a way that suggests infatuation. Starting with the passage above, Mosconi writes that she loves Scopoli, esteems him, and caresses his image (letter 7 , July 23,1801 ). These are strong words for a mother-in-law, especially given the fact that Mosconi is never this ardent in her letters to her daughter Laura. To her daughter, she writes, ' $[a] 11$ that is missing to complete my happiness is you... ${ }^{27}$ and 'you, my Lauretta, accept the most affectionate kiss from your mother, who will soon begin to grow tired of not seeing you. ${ }^{28}$ In comparison to the following passages written to Scopoli, the language she uses with Laura is restrained:

All that I can tell you, oh dear, is that I think of you very often, and no less strong is my desire to see you, to rejoice in your sweet company, and that my separation from this so precious son of my choice is oh so very painful. ${ }^{29}$

Again in letter 3, Mosconi writes,

In me you have a fond mother, a friend who honours and esteems you, an admirer of your virtues, and someone who loves your heart alone. My daughters are your tender sisters, who love you because you are made to wring the heart of whoever can recognize virtuous sensibility. ${ }^{30}$

How can we explain Mosconi's strong statement of feeling for her son-in-law? Why does she supplement her expressions of maternal sentiment with the language of romance? One possible explanation is that it is, in some ways, what the circumstance requires of her. Although there has clearly been an agreement struck between Scopoli and Mosconi 
regarding an engagement before the correspondence begins, the reader gets the impression that the fish has yet to be hooked; Scopoli still needs to be flattered and seduced, and yet Laura is not available to fulfil this role until letter $9 .^{31}$ Therefore, I would like to suggest that Mosconi functions as a romantic proxy until Laura and Scopoli establish an independent relationship.

This interpretation can be further supported by the way in which Mosconi talks about the marriage project in her first letters, which is to say, as if it were hers and Scopoli's alone. By framing the situation in this way, Mosconi seems to bind them together in a romantic union. In letter 6 (July 16, 1801), for example, which is essentially a letter of apology and reassurance for having bemoaned his jobless state, Mosconi writes:

I am so touched and sad after having received your last letter that I cannot be at peace before you know my true feelings. Oh my son! (a name my heart will always employ with equal affection) how could I ever have thought of robbing you of your pride, when all I sought to do was bemoan a sad fate, the only barrier to achieving your wishes and mine? ${ }^{32}$

Again, in letter 7 (July 23,1801), she states that his welfare is close to her heart, and, in a truly striking passage in letter 4 (July 5,1801 ) deplores 'the inveterate uses of society and luxury' to which 'the most delicious sensations of two hearts perhaps made for one another sacrifice themselves ${ }^{\prime 3}{ }^{33}$ which is to say, hers and Scopoli's!

At this point, they are the only ones who suffer from cruel and deep-rooted social custom. After letter 11, however, when his relationship with Laura is established, Laura is included as the third party who wishes for circumstances to right themselves. In letter 13 (1 de Complem.tris [September 18], 1801), she refers obscurely to 'our wishes' (nostri desideri) or, and in letter 15 (October 3,1801 ) to 'our common hopes' (delle comuni nostre speranze), and in letter 29 of January 26, 1802, refers several times in the first person plural form (noi) to their hopes and desires. More explicit is her formulation of October 18, 1801, where she writes, '[w]ould that the post be one which would fulfil we three in our single desire', ${ }^{34}$ and her statement that Scopoli's transfer to Verona would do so much good for 'three objects at once ${ }^{35}$ in letter 41 (April $18,1802)$. This is not to say that after the beginning of August Mosconi does not express her wishes for his future in her own name: she does. What changes is that she no longer speaks of the marriage project as hers and Scopoli's alone.

The modification in the way Mosconi refers to the marriage project reflects a more profound change in the nature of the correspondence: Mosconi has ceded her romantic role to her daughter. The change 
happened relatively quickly. In her first letters to Scopoli, mention of Laura almost gets lost in among the other news and Mosconi's own flattery. In letter 1, Laura is not mentioned at all; in letter 2, a three-page letter, she mentions that she will miss Laura if she leaves Verona, that Laura is learning English, and sends greetings from her in the last line; in her third, she sends only her daughter's greetings. In all, Laura does not figure prominently until letter 8 (August 2, 1801), written after Scopoli and Laura appear to have had some sort of disagreement.

Mosconi is still as enthusiastic about Scopoli, but in this instance her affection is closely linked to his relationship with Laura.

Oh how happy I would be if instead of crying over the difficult situation of the heart of my beloved son, I could sweeten his bitter circumstance with a happier prospect: but, my dear, I see that I am condemned to cry for you, for me and for L... . So often, I say to myself, and forgive me my folly, but why is he so lovable, so virtuous, so exquisitely sensitive, and why do I love him so? You, badly thought of by my tender L... ? Oh, do not believe it $!^{36}$

This letter is somewhat transitional, where her 'folly' for him coexists with her assurances of Laura's own warm feelings towards him. Already in letter 9, however, written just three days later, she is focusing more strongly still on Laura's feelings. Almost the entire letter is devoted to describing how Laura is spending her time in this moment of tension between the new couple. Also, interestingly, Scopoli and Laura seem to have established a relationship which Mosconi respects. Although her daughter tells her how she is feeling, she also forbids her to share it with Scopoli and Mosconi complies. Furthermore, it is the young couple who now share the excitement of reunion, and who dream of being together, as well as mourning their mutual absence.

Oh friend! Oh son! and to whom and for whom can she live and think? I make her laugh as much as I can. If I threaten to ask for your help and to tell you all, she gives a cry, begs me and implores me not to do it; I watch to see that she is not alone too often, that is, I suppose, with you: thus, between good and bad do we spend the long hours far from you, anticipating not a little your return, and trembling at your perhaps brief absence. ${ }^{37}$

The shift in Scopoli's relationship with Laura is also confirmed by one line in the following letter (11, 16 Fruttifero [September 3], 1801), in which Mosconi writes, '[i]n the mean time, my son, you uphold our common hopes; already it is no longer forbidden to love and to correspond with the object that loves you. ${ }^{38}$ After this letter, Mosconi forever abandons the role of romantic proxy. Her remarks towards Scopoli are affectionate 
and warm, but she respects and encourages Scopoli's greater intimacy with Laura.

The meshing of parent and romantic proxy is not the only instance in which Mosconi's roles are integrated; the roles of surrogate parent and in-law are also difficult to separate. The best illustration is Mosconi's desire to bring Scopoli into the fold of the family. She cultivates intimacy between Scopoli and her family in two ways. The first is through the relation of family news. In her first letter to Scopoli, Mosconi only mentions her family and friends at the end of the letter, writing, '[d]aughters [and] friends miss you [and] send greetings. ${ }^{39}$ In letter 2, she talks a little bit about what Laura is doing, and sends greetings only from Laura and Don Antonio Zamboni (who figures in almost every letter, and presumably had a close relationship with the family, and Mosconi and Laura in particular. June 13,1801). She signs in the same way in letter 3 (June 25,1801). In letter 4, Mosconi begins to include some family news in her letter, stating that the family is going to her country home, Novare, and sends greetings from the whole family (July 5, 1801). Mosconi offers more specific news in letter 5 . She talks about the health of her children - not only Laura, but also Clarina and Marietta - in detail for the first time (July 9, 1801). The next progression towards intimacy occurs in letter 9, just after Laura and Scopoli have developed an independent relationship; in this letter, Mosconi enumerates the people who send Scopoli greetings, signing, '[a]ccept the most tender greetings first from Lauretta, then from Marietta, Pindemonte, D.A., my brother and D. Bernardo. ${ }^{40}$ From this point on, family members are often enumerated in the greetings they send, and Mosconi writes in more and more detail about the health of her children.

A second way in which intimacy and trust is established between Scopoli and Mosconi's family is the request and fulfilment of favours. The favours that Mosconi does for Scopoli are in some sense structural: she uses her contacts to arrange for employment for him. In many ways, however, her assistance is taken for granted, and thus rarely expressed. The only other favour Scopoli seems to have asked for comes in the negotiation phase, where he asks Mosconi to write to Sebastiano Salimbeni to publish his work. ${ }^{41}$ For her part, Mosconi is not so shy about asking for a variety of services. She thanks him for visiting her sister (letter 8, August 2, 1801), and, more seriously, asks him to get her brother out of trouble with the police (letter 10, August 21, 1801).

Both the relation of news and the asking of favours implies a cultivation of intimacy which is ambiguous in its aim. Does Mosconi truly feel like a second mother to him, or is she cementing the deal that would assure her daughter a safe future? Her expressions of affection, as well as her use of the ' $t u$ ' form, as noted above, imply the former, whereas the 
logic of the correspondence implies the latter: in her negotiations with Scopoli, she works more in her daughter's interest than his. In fact, there is no need to choose between these options: as with the merging of romantic and parental roles, it is possible that the roles were not distinct in her eyes. This is reflected in the vacillation in Mosconi's signature in the first ten letters. She is either 'La Mamma', 'Mamma Elisa', 'Elisa', 'Mamma', 'La vostra Mamma d'elezione' (your chosen mother), and other slight variations of this form, all very similar, but each emphasizing a different aspect of role of parent or in-law. As we shall see, this ambiguity gets played out in more detail in the negotiation phase and so I will resume my discussion of it below.

\section{The Negotiation Phase}

The primary characteristic separating section one, the honeymoon phase, from section two, the negotiation phase, is the absence of the romantic voice, leaving the way open for Mosconi to concentrate her efforts on playing the roles of the surrogate parent and the in-law. As we shall see, many of the themes which appeared for the first time in section one reappear here, but with increased force. For example, because Mosconi's primary role in this section is to ensure that the necessary conditions for a successful match are fulfilled, she strongly assumes her role of in-law by bargaining with Scopoli and setting out the demands she requires of him. Her role as surrogate parent is expanded and reconfigured, as her expressions of affection are coupled with attempts to console Scopoli and counsel him through the marriage process. Finally, integration of these two roles continues to be played out in the intimacy she cultivates by asking favours of Scopoli and relating news regarding family health to him in order to cement their relationship.

In her role as in-law defending the interests of her daughter, Mosconi is necessarily placed in a position where she is Scopoli's 'opponent' in the demands she makes of him. Consequently, she sets out her conditions, which become more and more clear as the correspondence progresses. Whereas the relative importance of Scopoli having a post which is close to Verona, stable, honourable and which pays well in the first letters of this section is vague, the pressure of circumstance and time (which are Mosconi's real enemies in this battle, given the weakness of Scopoli's bargaining power) force Mosconi to make tough decisions as to what she is willing to compromise. In the end, it is clear that honour is the only one of the four requirements which is not negotiable. 
Beginning in letter 11, Mosconi starts to be more direct in terms of exactly what she expects from Scopoli: at this point, she writes, 'Mamma does not wish you to be rich, but established in an honourable post, one fitting the artless integrity of your disposition and your golden genius. ${ }^{42}$ She repeats the same sentiment in letter 17 (October 18, 1801), expressing her worry at his lack of success at the same time. In time, however, Scopoli formulates a clear career plan - he is proposing a career in the diplomatic service - and in Mosconi's reply (letter 28), we see another condition for his marriage to Laura come to the surface: proximity. She writes that although, for the many reasons Scopoli has pointed to, a diplomatic career would be a fine choice, she wonders whether he would have the courage to be so far away from his mother. Further on in the letter, however, we see that she has a more immediate concern with a career which would take Scopoli far from Verona: it would also mean that Laura would be far from her own mother. She writes, '[o]h my Scopoli, how could I ever consent to see such a precious daughter torn from my breast, to see her taken from me to lands far away! For pity's sake, spare me from so horrible an idea. ${ }^{43}$ If we return to previous letters, we can find prior indications that this is a concern for Mosconi in the marriage. First, she is keen on Scopoli becoming a Veronese citizen. Even before this, however, in letter 2, dated June 13, 1801, she signals her desire to keep Laura close by. Just after having stated that she regrets, although understands the departure of her acquaintance, Professore Simone Stratico, from Verona, ${ }^{44}$ she writes that she would not be so complacent if Laura were to leave: 'I do not promise, however, to be so philosophical if I were forced to see a more dear object separated from me, one which you know well, even for the best of reasons. ${ }^{45}$

As Mosconi's letters progress, her demands are stated more strongly. Initially, the relative importance of each condition is difficult to pin down. In letter 31 (January 23, 1802) for example, her desire to not have Laura very far away seems like a very loose preference, as she asks if Scopoli would be interested in a post in Verona, trying to convince him what a good reputation he has there, but does not insist on this matter. By contrast, the order of preferences in letter 32 (February 6, 1802) is quite different. Mosconi mentions the possibility of employment with the new government, which would fulfil several demands at once: it would be in Verona, it would be honourable and it would be profitable, although it would not necessarily be stable. Her insistence on proximity is especially surprising, given that in her last letters, it didn't necessarily seem to be a condition that Mosconi would take action to assure. Now she is willing to take money from the dowry to support them both with servants and children to have them stay close to her until their fortunes improve. To be fair, she does hope that his proximity will eventually result in stability 
- the better known he is in Verona, the better his chances of finding employment there. Nonetheless, she also seems to realize that his success is in no way certain.

Comparing the two letters, there are several indications that we should accord more importance to the emphasis she places on proximity and honour in relation to stability and financial compensation in this last letter. First, it is here that she sets out marriage arrangements in detail for the first time. She states that with the necessary caution, she would consign him the dowry, whereas he would use his provisions for his family and for his own pleasure. Also for the first time, she begins to consider the obstacles to the match concretely, writing,

You will need more details concerning this affair, which, as you see, could have many, many obstacles, which in a letter would be too long to list, and to which I am not so romantic as to be blind. ${ }^{46}$

Moreover, she herself notes a degree of difference in the tone of this letter; after having spoken in detail about the arrangements that would be made, she states that he now knows her true feelings:

You now know my secret and my sincere desires. Would that destiny smile on you once, and be assured of my warmest solicitude to render you happy within a few years. ${ }^{47}$

If Mosconi's tone seems more serious at this point in the correspondence, it is surely because Scopoli's employment prospects are improving and, in fact, he seems very close to getting a position. Mosconi thinks that he might be able to get a post through a connection to the Vice President of the newly created Italian Republic, Francesco Melzi d'Eril. ${ }^{48}$ Now that the new government structure is established, the waiting period is over: both Mosconi and Scopoli can now make the necessary arrangements to find him employment.

The importance of honour and proximity are again underscored in letter 35 (March 6, 1802), when Mosconi learns that Scopoli has an honourable position (about which we know very little, except that it was near Milan), but not one which is suitable enough to set wedding plans in motion. Not only is it not in Verona, but Mosconi also makes clear in this letter that it is only a step on the ladder towards the post which will win him Laura: it will give him the opportunity to be better known, and, in time, to obtain even better positions. Furthermore, in letter 40 (April 10, 1802) she states that she wants to see him in a position worthy of him, one which is secure, and would not injure his delicacy and honour, implying that the position he currently held did not fill these requirements. 
Just over a week later, however, Mosconi shows that honour is an even more important to her than proximity. It is true that Mosconi tries to make arrangements to have Scopoli transferred to Verona (letter 41, April 18, 1802; letter 42, April 20, 1802). Nevertheless, when it looks as if a position worthy of Scopoli has opened up, Mosconi is willing to accept that he take it, even if it meant that she would be separated from Laura. In letter 46 (May 5, 1802), Mosconi has just learned that Scopoli may be able to obtain the position of Secretary General of the Prefecture of an unspecified province. She is pleased with its advantages: it is an honourable post and comes with a large annual stipend. Nevertheless, several details concern her. She wants to know whether it is stable or not, and where the position is situated. Despite her worries, however, she says that the post is not to be refused, and in the end, accepts that he take it although it would separate her from Laura:

I also wanted to be able to make other arrangements preferable to my heart, but since this is impossible, I will adapt when the time comes to see myself separated from this daughter, so precious to me, to make your hearts happy. ${ }^{49}$

Therefore, in the end, honour is more important than proximity. Stability is also critical, but means nothing if not allied with one of these two elements. Financial compensation is a consideration, but a luxury more than a requirement. Luckily, Mosconi is not forced to sacrifice any of her desires, as soon after (letter 47, May 15, 1802) she learns that Scopoli will be appointed Secretary General and assigned to work in Verona. In her next letter (letter 48, May 23,1802), she confirms that he accepted the post and says that she is looking forward to seeing him in Verona soon.

Mother-in-law is not the only role played by Mosconi in this phase, however. As stated previously, Mosconi was negotiating more against time and circumstance than against Scopoli, who, instead of making counter-demands against Mosconi's insistence that he get a post, was instead working with her to ensure that he could meet her requirements. In some ways, this frees Mosconi up to use a more maternal voice in her dealings with Scopoli. She spends a good amount of time in her letters consoling him over his lack of employment, and assuring him that she still wants him as a son-in-law. She writes,

My dear Scopoli, so far away from my heart I find the need to pardon you that which you see as a fault, that in sharing your deep regret caused by your present unlucky situation, I am also conceiving plans to bring to fruition your hopes, which are at one with our common desires. Thus, calm your imagination, and know that I love you too much to ever want to destroy that which, although unintentionally, was in large measure of my own making. ${ }^{50}$ 
Not only does she console him, however; she also counsels him through various parts of the marriage negotiation. In their correspondence, there are a number of points at which she offers advice regarding his relation with his family. For example, in letter 28 (January 6, 1802), Mosconi advises Scopoli to make his career decision first and foremost for himself and for his family, for whom he will have to make provisions when he is married. In letter 36 (March 13, 1802), she states that now that he has a post, he must think of placing his sister and finding employment for his brother. Even her discussions of the dowry contain financial advice for Scopoli. She writes,

I hope that you will soon be able to place your sister, such that subsequently, with the pension of 8000 Milanese lire and the fruit of the dowry, you and the dear creature you would like for your precious and inseparable companion will be sufficiently comfortable and well-off. ${ }^{51}$

Granted, these are issues which could affect Laura's marriage if not properly dealt with before the wedding, but still, we are left with the impression that it is Mosconi who knows the ins and outs of this process, ${ }^{52}$ and that she is guiding Scopoli through it. Because she is older and belongs to a different social class, she finds herself in the position of mentor with regard to Scopoli. Paradoxically, then, as well as being opposed to Scopoli in the marriage negotiation, Mosconi is also on his side.

Moreover, Mosconi seems to feel genuine affection for Scopoli. She makes clear time and again how important Scopoli's personal qualities are to her. Not only is he a man who possesses character traits that she admires, such as honesty, delicacy and virtue (letter 4, July 5, 1801; letter 6 , July 16, 1801; letter 7, July 23 , 1801; letter 15 , October 3, 1801), but she also feels that she and he have a special connection. For example, she states from the beginning that she feels true maternal affection for him, writing that she will always call him her son (letter 6, July 16, 1801), and that she regards him as one of her own children (letter 7, July 23, 1801). This sentiment is further reinforced later in this section of the correspondence, even when such expressions of exuberance become more rare. Just after he has obtained a position in Milan, signifying continued separation, Mosconi writes,

I know that you misunderstood a passage in my last letter, but with it I wanted to make you understand that not all my sons-in-law are sons, as you will always be, just as I will always be your tender Mother, and I hope that in time I can give you unequivocal proof. ${ }^{53}$ 
Mosconi's maternal feelings for Scopoli are not the only theme upon which she expands in this section, though. Her desire to integrate and attach Scopoli to the family through sharing news about family health, creating opportunities for personal contact and asking favours is also much more present. For example, even though Mosconi makes more references to her health than any one else's $s{ }^{54}$ Scopoli is privy to details not only about Laura's well-being, which would naturally be of interest to him, but also to information about that of Mosconi's daughters Marietta and Clarina, who both had to undergo operations ${ }^{55}$ Furthermore, at the same time as Scopoli becomes more intimately acquainted with his future in-laws, Mosconi also seems to want to establish contact with Scopoli's mother, sister and brother. She personally does not have the opportunity to meet them, but was surely implicated in the decision to have Marietta and her family stay with them in Milan on their way to relocating in Marseille. ${ }^{56}$ In terms of favours, she asks him to send a copy of a Monti tragedy to Pindemonte (letter 28, January 6, 1802). Also, Scopoli has become one of Mosconi's contacts, meaning that she sends him people who are interested in making his acquaintance, presumably to ask favours of their own. ${ }^{57}$ Finally, Mosconi asks a number of personal favours, including asking him for souvenirs for the family (letter 14, 3 Vendemiaso [September 20], 1801), asking him to get passports for a friend of hers who wants to work in France (letter 42, April 20,1802), and finally for him to ask his employer to help her brother get his money back for a tax or duty he was forced to pay (letter 45, May 1, 1802).

The exchange of influence and services allows both Mosconi and Scopoli to gradually assume the heightened responsibility that their new relationship requires. It is clear that this, in conjunction with the increased contacts between the two families, is the way in which the alliances that the marriage entails are secured. What is less clear is how to categorize this behaviour: surrogate parent or in-law? Again, the answer is both, although this is not to say that their integration does not sometimes give rise to tensions. In letter 46, for example, after having told Scopoli that he must rectify his financial situation, Mosconi writes,

Forgive me if I enter into certain minute economic details with you; in truth, I would like to have them dealt with through a mutual friend, rather than deal with such matters with you. ${ }^{58}$

Her embarrassment arises from the fact that her exacting demands for the match, where she is clearly working in her own and her daughter's best interests in opposition to Scopoli, belie her statements that she makes no distinction between Scopoli and her own children, and that her interests mirror his own. ${ }^{59}$ 


\section{Resolution}

In contrast with the previous two phases, there is very little to say about the resolution phase. Because Scopoli has obtained a post which satisfies Mosconi and because the terms of the marriage have been settled, the principal conflict has been resolved and the tension disappears. Furthermore, as of June 1802, Scopoli is living in Verona, meaning that there is no more reason to continue their correspondence. In fact, these last three letters are written from Novare. The first announces her imminent return to Verona with Laura, the second is a letter of introduction, while the last letter of this year is a simple assurance that a spat she had with Laura will be quickly resolved (letter 49, June 13, 1802; letter 50, June 16, 1802; letter 51, August 18, 1802).

\section{Summary}

The significance of the correspondence is twofold. First, it provides us with the opportunity to evaluate the expression of power in a context which was not strictly institutionalized. Traditionally, Mosconi's negotiation of her daughter's marriage would be classed as belonging to the private sphere: she was looking after the welfare of her family by ensuring that all of her daughters were well-placed. In doing so, however, we can see that she exerts social and political influence that should make us call into question the tendency in both women's history and cultural history to presume that the public sphere was the only sphere in which one had access to legitimate power. This presumption, I think, underlies the search for 'public' women in the eighteenth century. For example, both Dena Goodman and Paula Findlen seek to bring to light instances of women's more formal, institutionalized intellectual activity. More importantly, both assert that the men of the Enlightenment esteemed the work of women such as Laura Bassi and the French salonnières. ${ }^{60}$ The evidence they provide counters more traditional views in European women's history that presume that a consensus existed concerning women's 'proper' domestic role and their 'feeble' intellect and that this concensus kept women from wielding power.

These studies are certainly vital to the field. They are very effective in holding up an alternate vision of women for our consideration - one in which women were not victimized and participated as equals in various intellectual domains. Nonetheless, the number of women who were able to break through institutional barriers to participate in public life was small. But this does not mean that women did not play a significant role in social and political life, one that is worthy of our attention. Less formal 
avenues of influence also provided women with access to power. This is one of the points that Sharon Kettering wants to make in her study of the patronage power of early modern French women. ${ }^{61}$ In opposition to a tendency in early modern women's history to define women as gradually becoming more and more powerless as they were confined to the private sphere, she proposes that noblewomen were actually able to wield an impressive amount of power through informal channels, including domestic patronage and brokerage of aristocratic and royal patronage. Even though Kettering doesn't speak in the language of public and private, her underlying message is the same. Informal, noninstitutional or private action is not necessarily action which is devoid of widespread social and political significance. Once we have recognized this point, the debate on where to place the line between private and public becomes a lot less urgent. Conceding that the majority of women did not participate in public-sphere institutions is not tantamount to conceding their powerlessness.

The second significance of Mosconi's correspondence is that it uncovers a potentially important difference between present-day conceptions of the proper configurations of family relations and the one that existed among nobility at the turn of the nineteenth century. I have identified three voices in Mosconi's letters: that of surrogate parent, that of lover and that of in-law. Certainly, circumstances dictate how and when these voices are used, but perhaps the most important detail uncovered by a thorough analysis of the letters is not only how they intertwine, but also merge, implying that the three roles are not necessarily antithetical to one another. This seems logical when we think of the ambiguity which still exists today between parent and in-law. More shocking to us is the lack of distinction between lover and surrogate parent or lover and in-law which sometimes makes its way into Mosconi's letters. Perhaps, however, this merging was not so shocking at the time, and was even expected in certain situations, such as when the child was unable to fulfil his or her romantic role. We have seen that these were the circumstances in which Mosconi adopted her romantic voice, the one with which she wooed Scopoli until he established an independent relationship with her daughter.

How can we be sure that we are dealing with a social phenomenon here, instead of one extraordinary case? We can't, of course, but a comparison with the case of Elisabeth Bégon, the wife of Claude Michel Bégon, the Governor of Trois Rivières until his death in 1748 , should give us pause. In her letters to her son-in-law, Honoré Michel de Villebois de la Rouvillière, she also adopted an ardent tone which has been interpreted as idiosyncratic, misplaced passion. ${ }^{62}$ Catherine Rubinger has sought to challenge this interpretation by explaining that her expressions 
of affection reflected conventional epistolary forms used in a variety of contexts, ${ }^{63}$ and that the feelings she described were manifestations of a particular type of closeness proper to family life in the eighteenth century. ${ }^{64}$ I think that the same can be said of many of the expressions of warmth in Mosconi's letters, but would take this even further to say that it does not necessarily negate the existence of a romantic overtone. This comparison suggests to me that the expression of parental affection was not necessarily at odds with playing the role of romantic proxy where the circumstances required. No answer can be conclusively drawn on the basis of two examples, but the concordance of these two cases seems to suggest that there is research needed here.

In brief, a study of Mosconi's letters to Scopoli raises questions about women and power and the configurations of family relations, although it is unable to provide any conclusive answers. This is always the disadvantage of undertaking single case studies: how much can we generalize from their results, especially in areas where there is a paucity of research? If we are interested in seriously analyzing and decoding mores, however, there is no substitute for poring over a small number of samples and then contextualizing them with comparisons or more general works. This is the process I hope to have begun in this article.

\section{SUSAN DALTON}

Postdoctoral Fellow, Stanford University

\section{Notes}

1 Funding for this research has been provided by a doctoral fellowship from the Social Sciences and Humanities Research Council of Canada. I would also like to thank Dominique Deslandres, Mary Johnson, John Dickinson and Josette Brun for helpful comments, and Claudia Ghezzi and Nicola Martino for verifying the Italian translations.

2 Marina Zancan, 'La donna', Letteratura italiana. Le Questioni, ed. A. Asor Rosa, 5 (Torino: Giulio Einaudi editore, 1982) 765-827; Fiorenza Taricone and Susanna Bucci, La condizione della donna nel XVII e XVIII secolo (Rome: Carucci, 1983); Luciano Guerci, La discussione sulla donna nell'Italia del Settecento. Aspetti e problemi (Turin: Tirrenia Stampatori, 1987); Fiorella D'Alia, La donna nel romanzo italiano del Settecento, con referimento particolare all'opera dell'Abate Pietro Chiari (Rome: Palombi, c1990).

3 Luisa Ricaldone, La scrittura nascota; Donne di lettere e loro immagini tra Arcadia e Restaurazione, (Fiesole: ed. Caduno, 1996); Luciano Guerci, La sposa obbediente. Donna e matrimonio nella discussione dell'Italia del Settecento (Turin: Tirrenia Stampatori, 1988). 
4 See Mary Trouille, Sexual Politics in the Enlightenment: Women Writers Read Rousseau (Albany: State University of N.Y. Press, c. 1997); Joan Wallach Scott, Only Paradoxes to Offer: French Feminists and the Rights of Man (Cambridge: Harvard University Press, 1996); Carole Pateman, The Sexual Contract (Stanford: Stanford University Press, 1988).

5 Marco Cerruti also speaks of the importance of undertaking this type of study in his edited volume, Il 'genio muliebre.' Percorsi di donne intelletuali fra Settecento e Novecento in Piemonte (Alessandria: Edizioni dell'orso, 1990).

6 Giuseppe Franco Viviani, 'Il Conte Giovanni Scopoli', Studi storici veronesi Luigi Simeoni 15-17 (1966-67) 225.

7 Luisa Ricaldone, 'Premessa', Al mio caro ed incomparabile amico. Lettere di Elisabetta Mosconi Contarini all'abate Aurelio De' Giorgi Bertola, ed. Luisa Ricaldone (Padua: Editoriale Programma, 1995) 9.

8 Angelo Fabi, 'Giovanni Scopoli e Maurizio Bufalini', Atti del Convegno Maurizio Bufalini. Medicina, scienza e filosofia, Cesena, 13-14 novembre 1987, ed. Giuliano Pancaldi (Bologna: Editrice CLUEB, 1990) 165-72.

9 Fabi, ‘Giovanni' 165, 172.

10 Viviani, 'Il Conte' 226.

11 Francesco Schröder, Repertorio genealogico delle famiglie confermate nobili e dei titolati nobili esistenti nelle provincie venete, 1, 1830 (Bologna: Forni Editore, 1972) 264; Antonio Cartolari, Cenni sopra varie famiglie illustri di Verona (Bologna: Forni Editore, 1855) 66.

12 Angelo Fabi, 'Canzonetta veronese inedita di Aurelio Bertola', Studi in onore di Antonio Piromalli. Da Dante al secondo Ottocento, ed. Toni Iermano and Tommaso Scappaticci (Naples: Edizioni Scientifiche Italiane, 1993) 289.

13 Guy Chaussinand-Nogaret, La noblesse au XVIIIe siècle. De la Féodalité aux Lumières ([Paris]: Hachette, 1976) 163-79; Calixte Hudemann-Simon, La noblesse luxembourgeoise au XVIIIe siècle (Paris: Publications de la Sorbonne, 1985) 75-91; Jean Meyer, La noblesse bretonne au XVIIIe siècle (Paris: SEVPEN, 1966) 1140-46.

14 Viviani, 'Il Conte' 220.

15 Mosconi to Scopoli, Lettere al suo genere Antonio Scopoli, Carteggi b.473, Carteggio Scopoli, Biblioteca Civica di Verona, Verona, Italy. Unless otherwise indicated, all letters are from this collection; subsequently, I will only refer to the letter number and date.

16 Laura was the daughter not of Mosconi's husband, but of Aurelio Bertola, with whom Mosconi had an affair in the early 1780s. Ricaldone, 'Premessa' 13.

17 Calixte Hudemann-Simon makes this point in reference to the Luxemburg nobility in his La noblesse 79.

18 I only want to consider the negotiation of the marriage in this paper, and therefore will omit Mosconi's final letter, (letter 52, April 19, 1804), written a little over two years after the marriage took place, which relates family news.

19 'E perchè si difficili e ingrate sono le circostanze della vostra famiglia?' letter 4, July 5,1801 . I have decided not to correct any grammatical or spelling errors in Mosconi's text. All translations are my own.

20 'estrinseche circostanze' which 's'oppongono alla mutua nostra felicità.' 
21 'Debbo chiedervi, Scopoli mio, se inelinereste ad un impiego nella giurisprudenza? V'e chi di cuore s'adoprerebbe per farvelo ottenere. Oh Dio! e che volete? io non so cosa darei per vedervi in un onorato impiego, il qual vi ponesse in quella beata mediocrità, che sola barterebbe a compiere i comuni nostri voti. Possa il tempo o mitigare una così acerba, ma insieme bella passione, $\mathrm{o}$ cangiare favorevolmente l'ingiusta vostra fortuna.'

22 'Oh Scopoli mio, voi m'avete fatto sentire la mia inferiorità nella proposizione di viver meco a Novare, e non so io ciò che dovete per natura alla madre, di cui siete si virtuosamente figlio? Oh fortunatissima madre!'

23 'Oh dove trovare un figlio d'un miglior carattere, più secondo il mio cuore.'

24 'tante e si belle qualità morali un'anima più sensibile e più pura, un cuore fatto si veramente l'un per l'altro', July 16, 1801.

25 Benoît Melançon, Diderot épistolier: contribution à une poétique de la lettre familière au XVIIIe siècle (Québec: Fides, 1996) 149.

26 'figlio della mia elezione', letter 2, June 13, 1801.

27 'Non mi manca che te per essere pienamente contenta', letter 3, Elisabetta Mosconi to Laura Mosconi, June 1, 1803, Lettere alla figlia, Carteggi b.473, Carteggio Scopoli, Biblioteca Civica di Verona, Verona, Italy. Henceforth cited as Lettere alla figlia.

28 'Et tu Lauretta mia ricevi il più affettuoso bacio della tua Mamma, che presto comincia d'essere stanca di non vederti', letter 4, Elisabetta Mosconi to Laura Mosconi, June 4,1803, Lettere alla figlia.

29 'Ciò solo che posso dirvi, o caro, è ch'io penso assai spesso a voi, che non men vivo è in me il desiderio di rivedervi, di godere della si soave vostra compagnia, $\mathrm{e}$ che assai ma assai penosa m'è la separazione da cotesto si prezioso figlio della mia elezione', letter 2, June 13, 1801.

30 'Voi avete in me una tenera madre, un'amica che vi onora vi stima un ammiratrice delle vostre virtù, ed un'amante del solo vostro cuore. Le figlie mie sono le tenere vostre sorelle, che vi amano perchè voi siete fatto per i strappare il cuore di chi conosce cos'è una virtuosa sensibilità', letter 3, June 25, 1801.

31 There is no evidence that they have even spent any time together before letter 8 (August 2, 1801), when Mosconi speaks of Laura's opinion of him.

32 'Io sono così afflitta e dolente dopo la recezione dell'ultima vostra ch'io non ho pace, come prima voi non conosciate i veri miei sentimenti. Oh mio figlio! (che sempre con eguale affetto seguirà con tal nome chiamarvi il mio cuore) come avrei io mai pensato di mortificare il vostro amor proprio volendo soltanto lagnarmi d'una trista fortuna, sola contraria a' vostri e a miei voti?'

33 'usi inveterati della società e del lusso' to which 'si sacrifica le più deliziose sensazioni di due cuori forse fatti l'un per l'altro!'

34 'Voglia il cielo che l'impiego sia tale onde rendere consolati i nostri triplici in un sol voto', letter 17 .

35 'tre oggetti ad un tempo.'

36 'Oh quanto io sarei lieta se in luogo di piangere sull' affannosa situazione di cuore del mio diletto figlio, io potessi addolcirne l'amaro con una prospettiva più felice: ma mio caro, io veggomi condannata a piangere su voi, su me e su di $\mathrm{L}$...., io tal volta mi dico, e perdonatemi la mia follia, ma perchè mai è egli si amabile si 
virtuoso si squisitamente sensibile, e perchè l'amo io tanto? Voi mal noto alla tenera mia L..? Oh guardatevi dal crederlo!'

37 'Oh amico! Oh figlio! e a chi e per chi può ella vivere e pensare? Io la fo ridere più che posso, se la minaccio d'appellarmi a voi, e di tutto dirvi, ella dà un grido, mi prega e mi scongiura di non farlo; cerco che non istia troppo con se stessa, cioè io suppongo con voi: ecco come tra bene e male si passan l'ore lungi da voi, bramando non tanto poco il vostro ritorno, e tremando per la vostra forse non troppo lunge partenza', letter 9, August 5, 1801.

38 'Voi intanto figlio mio sostenete le comuni nostre speranze; già non v'è più disdetto d'amare e di corrispondere coll'oggetto che vi ama', letter 11, 16 Fruttifero [September 3], 1801.

39 'Le Figlie gli amici vi salutano vi bramano', 10 Pratile [May 30], 1801.

40 'Ricevete i saluti i più teneri prima di Lauretta, poi di Marietta, Pindemonte, D.A., mio fratello e D. Bernardo', August 5, 1801.

41 Even this favour he asks for through a letter to Laura. Letter 22, October 14, 1801.

42 'Mamma non vi brama ricco, ma stabilito in un posto onorifico e confacente all'aureo ingegno vostro, e a quell'ingenua probità dell'indole vostra', letter 11, 16 Fruttifero [September 3], 1801. We should be sceptical about Mosconi's statements that money is not a concern for her. While it is true that it is less important than other factors, Mosconi does continue to mention financial compensation as something to be taken into account, as we shall see below.

43 'Oh Scopoli mio, come mai potrei consentire di vedermi strappar dal seno una sì preziosa figlia, per vedermela portar in paesi lontani! per pietà risparmiatemene una si orribile idea', letter 28, January 6, 1802.

44 For Milan, presumably, as Mosconi asks Scopoli, who was stationed there, to give him her sincerest congratulations.

45 'Non mi prometterei però d'un eguale filosofia se io dovessi vedermi allontanato un più caro oggetto, che voi ben conoscete, quantunque si trattasse della più grande fortuna.'

46 'Più dettagli vi vorrebbero su questo affare il quale come voi vedete può aver molti e molti ostacoli, che in una lettera sarebbe troppo lungo a dire, e ch'io non sono poi tanto romanzesca per non vederli', letter 32, February 6, 1802.

47 'Voi conoscete ora il mio segreto e i sinceri miei voti, possa una volta sorridervi il destino, e siate sicur della mia più calda premura per rendervi fra qualque anno contento', letter 32, February 6, 1802.

48 The Italian Republic was established by Napoleon Bonaparte February 9, 1802, as a reorganization of the République cisalpine, of which he was elected president January 25, 1802. Mosconi made her comment about Scopoli's connection to Melzi in letter 33, February 13, 1802.

49 'Avrei altresi desiderato di poter fare altre disposizioni più analoghe al mio cuore, ma giacchè quest'è impossibile, io $\mathrm{m}$ 'adatterò a suo tempo ad allontanarmi anche questa a me tanto preziosa figlia per render felici i vostri cuori.'

50 'Caro Scopoli mio, io trovo cosi lungi dal mio cuore il bisogno di perdonar a voi ciò che vi pare una colpa, che nel divider coll'animo, come pur fa, l'attual vostra non lieta situazione, vado io pure sognando progetti per ravvicinare al possibile le speranze vostre in un co' nostri comuni voti. Calmate dunque l'immaginazion 
vostra, e sappiate ch'io v'amo troppo per voler distrugger mai ciò ch'è stata in gran parte, senza però che ne avessi l'intezione, opera mia', letter 29, January 16, 1802.

51 'Io vorrei che poteste ben presto collocare la sorella vostra, mentre poi in seguito con la pensione delle 8000 lire Milanesi e il frutto della dote vi sarebbe assai comodo e agiato il viver per voi, e per la diletta creatura che voi volete per vostra inseparabile e preziosa compagna', letter 46, May 5, 1802.

52 This comes out most clearly in letter 46, May 5, 1802, where Mosconi states that she would like his sister placed soon, presumably because she would be a drain on their finances if she continued to live at home.

53 'So che non avrete ben inteso un tratto della passata mia lettera, ma volea con ciò farvi capire che non tutti i Generi son figli, e che voi me lo sarete sempre, com'io vi sarò tenera Madre, e spero che a suo tempo potrò darvene delle prove non equivoche', letter 36, March 23, 1802.

54 After letter 9, Mosconi makes reference to her health in 14 letters, to Laura's in 11, to Clarina's in 7 and to Marietta's in 4. Mosconi's most common complaint is rheumatism in her left arm, which, according to letter 27, December 26, 1801, started in 1778 .

55 Mosconi writes about Marietta's operation in letter 21, October 7, 1801, and Clarina's in letter 38, March 27, 1802.

56 Fabi, 'Canzonetta' 283.

57 See letter 34, February 26, 1802; letter 50, June 16, 1802; letter 44, April 28, 1802. In all fairness, Mosconi also thought that Cesare Realdi, who hand delivered his own letter of introduction (letter 44), would be a useful acquaintance for Scopoli.

58 'Scusate s'io entro con voi in qualche minuto dettaglio economico; per la verità amerei più di farlo trattando con persona scambievolmente amica di quello di trattar su tali materie con voi', May 5, 1802.

59 For example, after Scopoli got his job in Milan, Mosconi wrote to him, 'In short, inform me of everything that concerns you, as you know that, henceforth, your interests can no longer be separate from my own' ('Insomma informatemi d'ogni cosa che può rigardar voi, mentre sapete che gli interessi vostri non possono oramai disgiungersi più da miei propri') letter 35, March 6, 1802.

60 Paula Findlen, 'Science as a Career in Enlightenment Italy: The Strategies of Laura Bassi', Isis 84 (1993) 441-69; Dena Goodman, The Republic of Letters: A Cultural History of the French Enlightenment (Ithaca: Cornell University Press, 1994).

61 Sharon Kettering, 'The Patronage Power of Early Modern French Noblewomen', The Historical Journal 32, 4 (1989) 817-41.

62 Catherine Rubinger, 'Love, or Family Love, in New France. A New Reading of The Letters of Madame Bégon', Man and Nature. Proceedings of the Canadian Society for Eighteenth-Century Studies 11 (1992) 187-99.

63 Rubinger, 'Love' 188.

64 Rubinger, 'Love' 188-91, 195-97. 